\title{
Antihyperlipidaemic Efficacy of Trachyspermum ammi in Albino Rabbits
}

\author{
Ijaz Javed ${ }^{1}$, Zia-Ur-Rahman ${ }^{1}$, Muhammad Z. Khan², Faqir Muhammad ${ }^{1}$, Bilal Aslam ${ }^{1}$, \\ Zahid Iqbal $^{1}$, Javed I. Sultan ${ }^{3}$, Ijaz Ahmad ${ }^{4}$
}

${ }^{1}$ Department of Physiology and Pharmacology, ${ }^{2}$ Department of Pathology, ${ }^{3}$ Institute of Animal Nutrition and Feed Technology, University of Agriculture Faisalabad, Pakistan, ${ }^{4}$ Department of Physiology and Biochemistry, University of Veterinary and Animal Sciences, Lahore, Pakistan

Received March 31, 2008

Accepted February 9, 2009

\begin{abstract}
The objective of the present study was to investigate the antihyperlipidaemic efficacy of Trachyspermum ammi (L) Sprague, seed (Ajowan) powder in albino rabbits. Hyperlipidaemia was induced with butter ad libitum and oral intubation of cholesterol $400 \mathrm{mg} / \mathrm{kg}$ body weight. Simvastatin, (Tablet survive ${ }^{\sqrt{R}}$ ) was used as a synthetic cholesterol lowering drug. The results suggest that $2 \mathrm{~g} / \mathrm{kg} \mathrm{T}$. ammi seed powder produced hypolipidaemic activity, rendering 49\%, $53 \%, 71 \%$ and $63 \%$ reduction in total lipids, triglycerides, total cholesterol and LDL-cholesterol, respectively. However, at this dosage level $62 \%$ increase in the value of HDL-cholesterol was induced by $T$. ammi seed powder. Nonetheless, $0.5 \mathrm{~g} / \mathrm{kg}$ and $1 \mathrm{~g} / \mathrm{kg} T$. ammi seed powder did not show antihyperlipidaemic activity.

T. ammi seed powder at the rate of $2 \mathrm{~g} / \mathrm{kg}$ and simvastatin $(0.6 \mathrm{mg} / \mathrm{kg}$ body weight $)$ were equally effective in treating hyperlipidaemia in albino rabbits. Moreover, this dosage level also significantly reduced the cholesterol content of liver tissue. It can be anticipated that the lipid lowering mechanism may involve enhanced removal or catabolism of lipoproteins, inhibition of HMG COA reductase, and/or inhibition of lysosomal lipid hydrolytic enzymes secreted by the liver.
\end{abstract}

Cholesterol, triglycerides, Ajowan, hyperlipidaemia, simvastatin

Hyperlipidaemia initiates the onset of abnormalities in lipid metabolism secondary to manifestations and progression of the atherosclerosis characterized by formation of fibro-fatty intimal plaques. Abnormalities in lipid metabolism are among the best known cardiovascular risk factors (Anderson et al. 1987). A safe and effective hypolipidaemic modality - pharmacological, physical or dietary - can be employed to evade the predisposition to coronary heart disease. There is both animal model and human evidence that this is due to improvement in underlying atherosclerotic lesions with the reduction of both the lipid and the sclerotic components (Blankenhorn 1989).

Several synthetic drugs have been reported to have serious side effects (Laurance and Bennett 1992; Javed et al. 1994; Bhandari et al. 2002). Therefore, like in other ailments, attention is also being directed to medicines of herbal origin to discover safer and cheaper drugs for hypolipidaemic activity (Shaila et al. 1997; Miura et al. 2003; Wei et al. 2003; Suber 2005; Visavadiya and Narasimhacharya 2005; Javed et al. 2006).

Trachyspermum ammi (L.) Sprague, locally known as Ajowan, is cultivated in many parts of Pakistan, India, Afghanistan, Egypt and Europe (Chopra 1985). This plant is reported to inhibit platelet aggregation (Srivastava 1988), to show antifungal effects (Dwivedi and Dubey 1993) and to decrease blood pressure (Aftab et al. 1995). The antihyperlipidaemic effect of T. ammi seed powder is still not well documented. Keeping in view the medicinal value, the present study was carried out to determine the antihyperlipidaemic effect of $T$. ammi seed powder in albino rabbits.

Address for correspondence:

Dr. Ijaz Javed, PhD

Department of Physiology and Pharmacology

University of Agriculture, Faisalabad 38040

Pakistan
Phone: +92 419200161 ext 3104

Email: sandhudrijaz@yahoo.com

http://www.vfu.cz/acta-vet/actavet.htm 


\section{Materials and Methods}

Thirty-six healthy albino rabbits of both sexes, free from any apparent clinical ailment, produced at the Department of Zoology, University of Agriculture, Faisalabad, Pakistan were kept under similar managemental conditions at the Department of Clinical Medicine and Surgery, University of Agriculture, Faisalabad Pakistan. The average body weight of all groups of albino rabbits ranged from 1.35 to $1.60 \mathrm{~kg}$. They were acclimatized for seven days. The rabbits were then randomly divided into six separate groups, each group consisting of six rabbits. Ear tags were used for identification and all of the animals were housed in individual iron cages at ambient temperature and provided a 12/12 h period of light/dark. The experiments were conducted with the prior approval by the Directorates of Research and Advanced Studies and with the consent of the Society of Ethics of Animals, University of Agriculture, Faisalabad. The rabbits were sacrificed according to the rules laid down by the Society of Ethics of Animals, University of Agriculture, Faisalabad, Pakistan.

The rabbits were provided alfalfa (lucerne) as routine feed. The feed was made available twice a day, usually in the morning and evening. Drinking water was available $24 \mathrm{~h}$ a day. While one group was strictly kept on the routine feed only, the rest of the groups were also fed butter ad libitum and cholesterol powder (Cholesterol 90\% E. Merck, Darmstadt, Germany) $400 \mathrm{mg} / \mathrm{kg}$ body weight in $5 \mathrm{ml}$ coconut as vehicle by oral intubation. Butter and cholesterol were fed to induce hyperlipidaemia (Kalhoro et al. 1996; Purohit and Daradka 2001; Javed et al. 2006).

Seeds of T. ammi were obtained from the Department of Botany, University of Agriculture, Faisalabad, Pakistan. The seeds were finely powdered in an electric grinder. This powder was then administered to the rabbits as an indigenous antihyperlipidaemic drug. Tablet survive ${ }^{\circledR}$ (simvastatin, $20 \mathrm{mg}$, Werrick Pharmaceuticals, Islamabad, Pakistan) was used as synthetic cholesterol lowering drug.

The powders of $T$. ammi seed and simvastatin were administered orally in $5 \mathrm{ml}$ of water with ball-tipped intubation tubes to individual hyperlipidaemic albino rabbits, in the morning at least one hour before normal routine feeding. The feeding and drug administration schedule are presented in Table 1. From 0-135 days, individual animals of each group had blood samples drawn aseptically at $0,30,60,90,105,120$ and 135 days from the jugular vein. The samples were then allowed to clot for $20 \mathrm{~min}$ at refrigeration temperature and then centrifuged at $1968 \mathrm{~g}$ for $5 \mathrm{~min}$. The separated serum was stored at freezing temperature until further analysis. Lipid profile indicators of individual animals from 0-135 days were determined in the serum of rabbits with reagent kits (Randox, Randox laboratories LTD, UK). Lipid profile indicators included total lipids, triglycerides, total cholesterol, high-density lipoprotein cholesterol (HDL-Cholesterol) and low-density lipoprotein cholesterol (LDL-Cholesterol).

Table 1. Feeding and drug administration schedule in rabbits during the experimental period of 0 to 135 days

\begin{tabular}{|c|c|}
\hline Groups & Schedule \\
\hline $\begin{array}{l}\text { Group I: Untreated control } \\
\text { on normal routine feed }\end{array}$ & Normal routine feed 0 to 135 days $+5 \mathrm{ml}$ distilled water \\
\hline $\begin{array}{l}\text { Group II: Untreated control } \\
\text { on butter and cholesterol }\end{array}$ & $\begin{array}{l}\text { Normal routine feed }+ \text { butter ad libitum }+ \text { cholesterol powder } \\
400 \mathrm{mg} / \mathrm{kg} \text { body weight in } 5 \mathrm{ml} \text { coconut oil as vehicle } 0 \text { to } 90 \text { days, } \\
\text { normal routine feed } 90 \text { to } 135 \text { days }\end{array}$ \\
\hline $\begin{array}{l}\text { Group III: Treated control } \\
\text { on synthetic cholesterol } \\
\text { lowering drug; Tablet } \\
\text { survive }^{\circledR} \text { (simvastatin) } \\
\end{array}$ & $\begin{array}{l}\text { Normal routine feed + butter ad libitum + cholesterol powder } \\
400 \mathrm{mg} / \mathrm{kg} \text { body weight in } 5 \mathrm{ml} \text { coconut oil as vehicle } 0 \text { to } 90 \text { days, } \\
\text { normal routine feed + Tablet survive }{ }^{\circledR} \text { (simvastatin, } 20 \mathrm{mg} \text { ) } \\
0.6 \mathrm{mg} / \mathrm{kg} \text { in } 5 \mathrm{ml} \text { water } 90 \text { to } 135 \text { days }\end{array}$ \\
\hline $\begin{array}{l}\text { Group IV: Trachyspermum } \\
\text { ammi seed powder }\end{array}$ & $\begin{array}{l}\text { Normal routine feed + butter ad libitum + cholesterol powder } \\
400 \mathrm{mg} / \mathrm{kg} \text { body weight in } 5 \mathrm{ml} \text { coconut oil as vehicle } 0 \text { to } 90 \text { days, } \\
\text { normal routine feed }+ \text { T. ammi seed powder } 0.5 \mathrm{~g} / \mathrm{kg} \text { in } 5 \mathrm{ml} \text { water } \\
90 \text { to } 135 \text { days }\end{array}$ \\
\hline $\begin{array}{l}\text { Group V: Trachyspermum } \\
\text { ammi seed powder }\end{array}$ & $\begin{array}{l}\text { Normal routine feed }+ \text { butter ad libitum }+ \text { cholesterol powder } \\
400 \mathrm{mg} / \mathrm{kg} \text { body weight in } 5 \mathrm{ml} \text { coconut oil as vehicle } 0 \text { to } 90 \text { days, } \\
\text { normal routine feed }+ \text { T. ammi seed powder } 1 \mathrm{~g} / \mathrm{kg} \text { in } 5 \mathrm{ml} \text { water } \\
90 \text { to } 135 \text { days }\end{array}$ \\
\hline $\begin{array}{l}\text { Group VI: Trachyspermum } \\
\text { ammi seed powder }\end{array}$ & $\begin{array}{l}\text { Normal routine feed + butter ad libitum + cholesterol powder } \\
400 \mathrm{mg} / \mathrm{kg} \text { body weight in } 5 \mathrm{ml} \text { coconut oil as vehicle } 0 \text { to } 90 \text { days, } \\
\text { normal routine feed }+ \text { T. ammi seed powder } 2 \mathrm{~g} / \mathrm{kg} \text { in } 5 \mathrm{ml} \text { water } \\
90 \text { to } 135 \text { days }\end{array}$ \\
\hline
\end{tabular}


At the completion of the experiment, i.e. at post treatment day 135, the rabbits of all groups were sacrificed and the livers of individual animals were removed free from fat and connective tissue and stored at $-20{ }^{\circ} \mathrm{C}$ until analysis. Total cholesterol was extracted from the liver by a method described by Choi 1991 . The concentration of total cholesterol in this extract was determined by using commercial reagent kit as mentioned above.

Significance of the differences between the $T$. ammi seed powder-treated and untreated control or treated control groups was tested using Student's $t$-test. To assess the antihyperlipidaemic effect of T. ammi seed powder on the cholesterol contents of liver tissue, comparison between the treatment groups, treated control group and/or untreated control group was performed by analysis of variance (ANOVA) followed by Duncan's Multiple Range Test (DMR). In all tests the criterion of significance was $(P<0.05)$.

\section{Results and Discussion}

Hyperlipidaemia produced as a result of 0-90 days feed butter ad libitum and cholesterol $400 \mathrm{mg} / \mathrm{kg}$ body weight along with the normal routine feed is given in Fig 1. It is obvious that there was a 2.5- to 7-fold increase in lipid profile indicators at 90 days when compared to their respective values at day 0, while HDL-cholesterol was found having a 1 to 1.5 times decreasing trend. However, a 3.5- to 9-fold increase in these indicators has been reported in albino rabbits fed with atherogenic diet and cholesterol $(400 \mathrm{mg} / \mathrm{kg})$ for 120 days (Purohit and Daradka 2001).

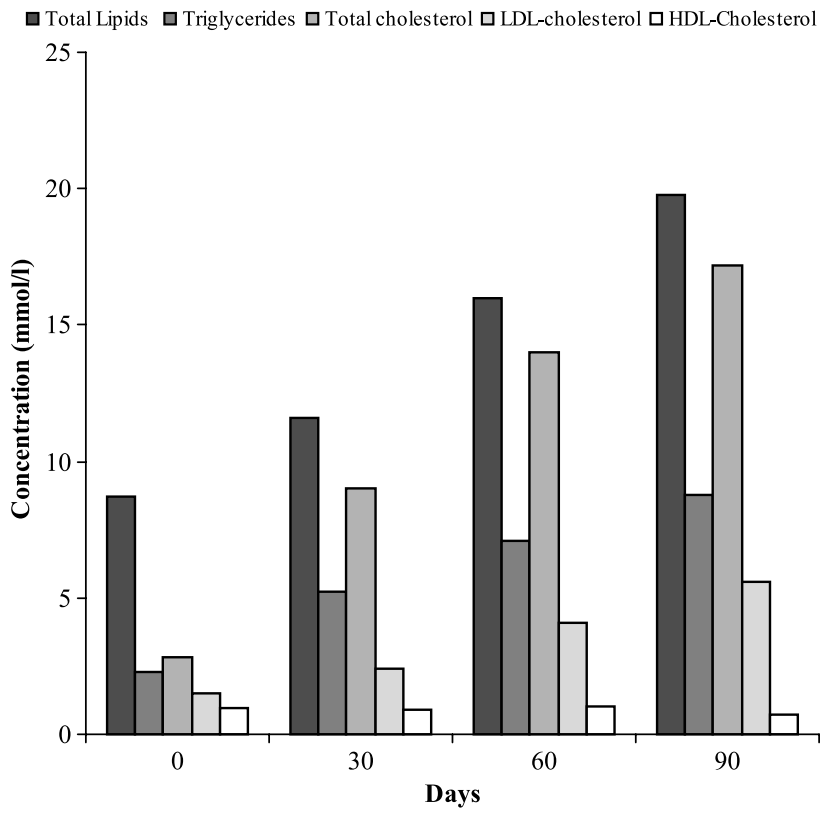

Fig. 1. Mean (mmol/l) concentrations of serum lipid profile in albino rabbits fed with butter and cholesterol $400 \mathrm{mg} / \mathrm{kg}$ body weight

Antihyperlipidaemic efficacy of $T$. ammi seed powder at the rate of $0.5,1$ and $2 \mathrm{~g} / \mathrm{kg}$ body weight against lipid profile indicators is shown in Tables 2-6. It can be seen that in case of $0.5 \mathrm{~g} / \mathrm{kg}$ and $1.5 \mathrm{~g} / \mathrm{kg}$ dosage levels lipid profile indicator values at post-cholesterol feeding day 90 were not significantly altered $(P>0.05)$ at post-treatment days 105,120 and 135 . However, the reductions in lipid profile indicators induced by $2 \mathrm{~g} / \mathrm{kg}$ T. ammi seed powder was found significant $(P<0.05)$.

From the results it is clear that $T$. ammi seed powder at the level of $2 \mathrm{~g} / \mathrm{kg}$ significantly lowered $(P<0.05)$ the lipid profile indicators, including total lipids at 135 , triglycerides 
Table 2. Mean \pm SEM values of total lipids $(\mathrm{mmol} / \mathrm{l})$ and their percent reductions in the serum of hyperlipidaemic rabbits $(\mathrm{n}=6)$ after treatment with Trachyspermum ammi seed powder and simvastatin

\begin{tabular}{|c|c|c|c|c|c|c|c|}
\hline \multirow{2}{*}{ Groups } & \multirow{2}{*}{$\begin{array}{c}\text { Post } \\
\text { cholesterol } \\
\text { feeding } \\
\text { day } \\
90\end{array}$} & \multicolumn{3}{|c|}{ Post treatment days } & \multicolumn{3}{|c|}{$\begin{array}{l}\text { Percent reduction on post } \\
\text { treatment days }\end{array}$} \\
\hline & & 105 & 120 & 135 & 105 & 120 & 135 \\
\hline Group I & $8.6 \pm 0.9$ & $8.8 \pm 0.9$ & $8.9 \pm 0.8$ & $8.5 \pm 0.8$ & - & - & - \\
\hline Group II & $23.7 \pm 1.8$ & $22.4 \pm 1.6$ & $22.0 \pm 1.5$ & $20.3 \pm 1.4$ & - & - & - \\
\hline Group III & $20.8 \pm 1.6$ & $8.0 \pm 0.9^{*}$ & $7.8 \pm 0.8^{*}$ & $7.7 \pm 0.6^{*}$ & $62 \pm 5.1$ & $63 \pm 6.0$ & $63 \pm 5.7$ \\
\hline Group IV & $19.3 \pm 1.6$ & $18.5 \pm 1.5$ & $16.0 \pm 1.4$ & $15.3 \pm 1.4$ & $4 \pm 0.6$ & $17 \pm 1.7$ & $20 \pm 2.2$ \\
\hline Group V & $23.3 \pm 2.3$ & $18.9 \pm 2.0$ & $17.6 \pm 1.9$ & $15.3 \pm 1.7$ & $19 \pm 2.0$ & $24 \pm 2.5$ & $34 \pm 3.8$ \\
\hline Group VI & $21.0 \pm 2.0$ & $16.2 \pm 2.0$ & $15.3 \pm 1.8$ & $10.7 \pm 0.6$ & $23 \pm 2.6$ & $27 \pm 3.0$ & (a) $49 \pm 4.2$ \\
\hline
\end{tabular}

$\mathrm{n}=$ Number of animals in each group

* = Significantly less $(P \leq 0.05)$ than the pretreatment value at 90 days

$@=$ Non-significantly $(P>0.5)$ different from respective value obtained with Tablet survive ${ }^{\circledR}$ (simvastatin)

Table 3. Mean \pm SEM values of triglycerides $(\mathrm{mmol} / \mathrm{l})$ and their percent reductions in the serum of hyperlipidaemic rabbits $(\mathrm{n}=6)$ after treatment with Trachyspermum ammi seed powder and simvastatin

\begin{tabular}{|c|c|c|c|c|c|c|c|}
\hline \multirow{2}{*}{ Groups } & \multirow{2}{*}{$\begin{array}{c}\text { Post } \\
\text { cholesterol } \\
\text { feeding } \\
\text { day } \\
90 \\
\end{array}$} & \multicolumn{3}{|c|}{ Post treatment days } & \multicolumn{3}{|c|}{$\begin{array}{l}\text { Percent reduction on post } \\
\text { treatment days }\end{array}$} \\
\hline & & 105 & 120 & 135 & 105 & 120 & 135 \\
\hline Group I & $2.5 \pm 0.5$ & $2.5 \pm 0.5$ & $2.4 \pm 0.5$ & $2.4 \pm 0.5$ & - & - & - \\
\hline Group II & $8.3 \pm 0.8$ & $8.0 \pm 0.9$ & $7.5 \pm 1.0$ & $7.1 \pm 0.7$ & - & - & - \\
\hline Group III & $8.5 \pm 0.9$ & $3.5 \pm 0.6^{*}$ & $2.5 \pm 0.6^{*}$ & $2.2 \pm 0.5$ & $59 \pm 7.3 *$ & $70 \pm 7.8$ & $74 \pm 8.7$ \\
\hline Group IV & $10.8 \pm 1.1$ & $10.1 \pm 0.9$ & $9.2 \pm 0.9$ & $8.6 \pm 0.8$ & $6 \pm 1.0$ & $15 \pm 1.7$ & $20 \pm 2.0$ \\
\hline Group V & $10.7 \pm 1.2$ & $9.9 \pm 1.1$ & $8.4 \pm 1.0$ & $7.7 \pm 0.9$ & $8 \pm 0.9$ & $22 \pm 1.9$ & $28 \pm 2.2$ \\
\hline Group VI & $9.0 \pm 1.2$ & $6.2 \pm 0.9$ & $4.7 \pm 0.8^{*}$ & $4.0 \pm 0.6^{*}$ & $31 \pm 3.6$ & $48 \pm 5.0$ & (a) $55 \pm 5.6$ \\
\hline
\end{tabular}

$\mathrm{n}=$ Number of animals in each group

* = Significantly less $(P \leq 0.05)$ than the pretreatment value at 90 days

$@$ = Non-significantly $(P>0.5)$ different from respective value obtained with Tablet survive ${ }^{\circledR}$ (simvastatin)

Table 4. Mean \pm SEM values of total cholesterol $(\mathrm{mmol} / \mathrm{l})$ and their percent reductions in the serum of hyperlipidaemic rabbits $(\mathrm{n}=6)$ after treatment with Trachyspermum ammi seed powder and simvastatin

\begin{tabular}{|c|c|c|c|c|c|c|c|}
\hline \multirow{2}{*}{ Groups } & \multirow{2}{*}{$\begin{array}{c}\text { Post } \\
\text { cholesterol } \\
\text { feeding } \\
\text { day } \\
90\end{array}$} & \multicolumn{3}{|c|}{ Post treatment days } & \multicolumn{3}{|c|}{$\begin{array}{l}\text { Percent reduction on post } \\
\text { treatment days }\end{array}$} \\
\hline & & 105 & 120 & 135 & 105 & 120 & 135 \\
\hline Group I & $2.7 \pm 0.4$ & $2.6 \pm 0.4$ & $2.8 \pm 0.4$ & $2.7 \pm 0.4$ & - & - & - \\
\hline Group II & $16.8 \pm 1.3$ & $15.3 \pm 1.3$ & $14.8 \pm 1.2$ & $14.4 \pm 1.1$ & - & - & - \\
\hline Group III & $18.8 \pm 2.5$ & $8.4 \pm 1.0^{*}$ & $5.4 \pm 0.8^{*}$ & $2.7 \pm 0.7^{*}$ & $55 \pm 4.7$ & $71 \pm 5.2$ & $85 \pm 6.6$ \\
\hline Group IV & $19.4 \pm 1.7$ & $17.0 \pm 1.5$ & $15.5 \pm 1.4$ & $15.0 \pm 1.4$ & $12 \pm 0.8$ & $20 \pm 1.2$ & $22 \pm 1.1$ \\
\hline Group V & $21.2 \pm 2.5$ & $18.7 \pm 2.2$ & $16.6 \pm 1.9$ & $15.1 \pm 1.8$ & $12 \pm 1.4$ & $22 \pm 1.5$ & $28 \pm 1.7$ \\
\hline Group VI & $18.1 \pm 2.3$ & $10.9 \pm 1.5^{*}$ & $10.5 \pm 1.2 *$ & $5.2 \pm 0.8^{*}$ & $40 \pm 3.7$ & $42 \pm 4.0$ & (a) $71 \pm 6.0$ \\
\hline
\end{tabular}

$\mathrm{n}=$ Number of animals in each group

* = Significantly less $(P \leq 0.05)$ than the pretreatment value at 90 days

$@=$ Non-significantly $(P>0.5)$ different from respective value obtained with Tablet survive ${ }^{\circledR}$ (simvastatin) 
Table 5. Mean \pm SEM values of LDL-cholesterol $(\mathrm{mmol} / \mathrm{l})$ and their percent reductions in the serum of

hyperlipidaemic rabbits $(\mathrm{n}=6)$ after treatment with Trachyspermum ammi powder and simvastatin

\begin{tabular}{|c|c|c|c|c|c|c|c|}
\hline \multirow{2}{*}{ Groups } & \multirow{2}{*}{$\begin{array}{c}\text { Post } \\
\text { cholesterol } \\
\text { feeding } \\
\text { day } \\
90\end{array}$} & \multicolumn{3}{|c|}{ Post treatment days } & \multicolumn{3}{|c|}{$\begin{array}{l}\text { Percent reduction on post } \\
\text { treatment days }\end{array}$} \\
\hline & & 105 & 120 & 135 & 105 & 120 & 135 \\
\hline Group I & $1.6 \pm 0.2$ & $1.5 \pm 0.2$ & $1.7 \pm 0.2$ & $1.5 \pm 0.2$ & - & - & - \\
\hline Group II & $7.0 \pm 0.8$ & $6.3 \pm 0.7$ & $6.3 \pm 0.6$ & $6.2 \pm 0.6$ & - & - & - \\
\hline Group III & $5.6 \pm 0.7$ & $2.2 \pm 0.4^{*}$ & $2.0 \pm 0.4^{*}$ & $1.5 \pm 0.3^{*}$ & $61 \pm 4.9$ & $64 \pm 5.0$ & $72 \pm 5.5$ \\
\hline Group IV & $7.0 \pm 0.7$ & $6.5 \pm 0.6$ & $5.8 \pm 0.6$ & $5.5 \pm 0.6$ & $7 \pm 0.6$ & $17 \pm 1.3$ & $21 \pm 1.5$ \\
\hline Group V & $5.5 \pm 0.6$ & $4.7 \pm 0.5$ & $4.4 \pm 0.5$ & $4.2 \pm 0.4$ & $15 \pm 1.7$ & $20 \pm 2.5$ & $24 \pm 2.9$ \\
\hline Group VI & $7.1 \pm 0.5$ & $4.2 \pm 0.4^{*}$ & $3.5 \pm 0.4^{*}$ & $2.6 \pm 0.3^{*}$ & $40 \pm 3.5^{*}$ & $50 \pm 4.3$ & (a) $63 \pm 5.1$ \\
\hline
\end{tabular}

$\mathrm{n}=$ Number of animals in each group

* = Significantly less $(P \leq 0.05)$ than the pretreatment value at 90 days

$@$ = Non-significantly $(P>0.5)$ different from respective value obtained with Tablet survive ${ }^{\circledR}$ (simvastatin)

Table 6. Mean \pm SEM values of HDL-cholesterol $(\mathrm{mmol} / \mathrm{l})$ and their percent increases in the serum of

hyperlipidaemic rabbits $(\mathrm{n}=6)$ after treatment with Trachyspermum ammi powder and simvastatin

\begin{tabular}{|c|c|c|c|c|c|c|c|}
\hline \multirow{2}{*}{ Groups } & \multirow{2}{*}{$\begin{array}{c}\text { Post } \\
\text { cholesterol } \\
\text { feeding } \\
\text { day } \\
90\end{array}$} & \multicolumn{3}{|c|}{ Post treatment days } & \multicolumn{3}{|c|}{$\begin{array}{l}\text { Percent increase on post } \\
\text { treatment days }\end{array}$} \\
\hline & & 105 & 120 & 135 & 105 & 120 & 135 \\
\hline Group I & $1.0 \pm 0.1$ & $0.8 \pm 0.07$ & $1.1 \pm 0.1$ & $0.9 \pm 0.09$ & - & - & - \\
\hline Group II & $0.8 \pm 0.08$ & $0.8 \pm 0.09$ & $35 \pm 3.3$ & $37 \pm 3.7$ & - & - & - \\
\hline Group III & $0.7 \pm 0.04$ & $1.08 \pm 0.09 *$ & $1.14 \pm 0.1^{*}$ & $1.2 \pm 0.1^{*}$ & $54 \pm 4.8$ & $62 \pm 5.7$ & $72 \pm 6.2$ \\
\hline Group IV & $0.7 \pm 0.05$ & $0.7 \pm 0.06$ & $0.75 \pm 0.08$ & $0.8 \pm 0.07$ & $0 \pm 0$ & $7 \pm 0.2$ & $14 \pm 0.6$ \\
\hline Group V & $0.7 \pm 0.08$ & $0.73 \pm 0.08$ & $0.81 \pm 0.07$ & $0.85 \pm 0.06$ & $4 \pm 0.2$ & $15 \pm 0.7$ & $22 \pm 0.9$ \\
\hline Group VI & $0.7 \pm 0.03$ & $0.93 \pm 0.05 *$ & $1.02 \pm 0.06^{*}$ & $1.14 \pm 0.1^{*}$ & $32 \pm 2.1$ & $45 \pm 3.0$ & (a) $62 \pm 3.8$ \\
\hline
\end{tabular}

$\mathrm{n}=$ Number of animals in each group

* = Significantly higher $(P \leq 0.05)$ than the pretreatment value at 90 days

@ $=$ Non-significantly $(P>0.5)$ different from respective value obtained with Tablet survive ${ }^{\circledR}$ (simvastatin)

at 120 and 135, total cholesterol and LDL-cholesterol at 105, 120 and 150 post-treatment days. Similarly, HDL-cholesterol was found to have increased at all post-treatment days. Moreover, it can also be seen that $2 \mathrm{~g} / \mathrm{kg}$

Table 7. Mean \pm SEM values of total cholesterol $(\mathrm{mg} / \mathrm{g})$ in the liver of hyperlipidaemic albino rabbits at post treatment day 135 after treatment with Trachyspermum ammi seed powder and simvastatin

\begin{tabular}{|c|c|}
\hline Groups & Post treatment day 135 \\
Group I & $10.1 \pm 0.3 \mathrm{~A}$ \\
Group II & $17.4 \pm 0.3 \mathrm{C}$ \\
Group III & $11.0 \pm 0.5 \mathrm{~A}$ \\
Group IV & $16.2 \pm 0.7 \mathrm{C}$ \\
Group V & $15.5 \pm 0.4 \mathrm{~B}$ \\
Group VI & $9.6 \pm 0.2 \mathrm{~A}$ \\
\hline
\end{tabular}

Mean values followed by the same letters indicate non-significant difference $(P>0.05)$ of $T$. ammi seed powder and simvastatin produced statistically similar effects in terms of percentage reduction of lipid profile indicators at post-treatment day 135 .

Furthermore, the T. ammi seed powder more effectively decreased total cholesterol by $71 \%$ and then, in the descending order, LDL-cholesterol by $63 \%$, triglycerides by $53 \%$ and total lipids by $49 \%$ on post-treatment day 135 . However, a $62 \%$ increase in the value of HDL-cholesterol was induced by T. ammi seed powder after its medication in hyperlipidaemic albino rabbits. T. ammi seed 
powder at the rate of $2 \mathrm{~g} / \mathrm{kg}$ resulted in a significant lowering $(P<0.05)$ of total cholesterol of liver in comparison with cholesterol-fed rabbits (Table 7). Moreover, it is also evident from the table that the total cholesterol lowering effect of $2 \mathrm{~g} / \mathrm{kg}$ of $T$. ammi seed powder and simvastatin is non-significantly different $(P>0.05)$.

The relationship between cholesterol and coronary artery disease suggests that a reduction in cholesterol plasma level reduces the incidence of coronary events (Lipid Research Clinics Programme 1984). In the same way, hypertriglyceridaemia has been established as an independent risk factor for coronary atherosclerosis (Carlson and Bottiger 1981). A significant decrease of cholesterol (71\%) and triglycerides (53\%) after administration of $T$. ammi seed powder indicates its risk-reducing action.

There is an inverse relationship between plasma HDL-cholesterol level and coronary heart disease (Jahromi et al. 1993; Sharma et al. 2003). Moreover, apo-B-containing lipoprotein fractions are thought to be responsible for cholesterol deposition in atherosclerotic plaques (Choi 1991). Further, HDL alters the balance of non-esterified cholesterol between plasma and cell by increasing its utilization in the lecithin cholesterol acyl tranferase (LCAT) system to form cholesterol ester, which moves rapidly into the cell (Katzung 2001). So, an increase in HDL-cholesterol and a reduction in LDL-cholesterol would be advantageous clinically. In the present study the 63\% decrease in LDL-cholesterol and $62 \%$ increase in HDL-cholesterol after the administration of $T$. ammi seed powder may be of clinical significance. Furthermore, reduction in the total cholesterol of the liver may suggest a beneficial role of $T$. ammi in a hyperlipidaemic subject.

The possible mechanism of lipid alteration might be a cholestatic effect of T. ammi in the liver through enhanced removal or catabolism of lipoproteins or inhibition of HMG COA reductase and/or inhibition of lysosomal lipid hydrolytic enzymes secreted by the liver.

Thus the clinical benefits of T. ammi seed powder can be correlated with a decrease in LDL-cholesterol, an increase in HDL-cholesterol and a decrease in plasma triglycerides. Based on the results, it can safely be said that $T$. ammi seed powder and simvastatin are equally effective in treating hyperlipidaemia. Furthermore, comprehensive chemical and pharmacological investigations will be needed to elucidate the exact mechanism of these effects and to isolate the active principles responsible.

\section{Účinnost semen Trachyspermum ammi pro potlačení hyperlipidémie u albino králíků}

Cílem této studie bylo zjistit antihyperlipidemický účinek semen z rostliny Trachyspermum ammi (L) Sprague, též nazývané Ajowan, podávané ve formě šrotu albino králíkům. Hyperlipidémie byla indukována nabídkou másla ad libitum a podáváním cholesterolu v dávce $400 \mathrm{mg} / \mathrm{kg}$ živé hmotnosti perorální sondou. Dále byl podáván syntetický preparát na snižování cholesterolu simvastatin (Tablet survive ${ }^{\circledR}$ ). Z výsledků vyplývá, že $2 \mathrm{~g} / \mathrm{kg}$ drcených semen $T$. ammi vykazuje hypolipidemickou aktivitu a snižuje celkový obsah lipidů v krvi o 49\%, množství triglyceridů o 53\%, hladinu celkového cholesterolu o $71 \%$ a redukce LDL-cholesterolu činila $63 \%$. Na druhou stranu došlo v důsledku podání tohoto množství drcených semen T. ammi k nárůstu HDL-cholesterolu o $62 \%$. Podávání šrotu z semen $T$. ammi v dávkách $0.5 \mathrm{~g} / \mathrm{kg}$ a $1 \mathrm{~g} / \mathrm{kg}$ neprokázalo žádné antihyperlipidemické působení.

Drcená semena T. ammi v dávce $2 \mathrm{~g} / \mathrm{kg}$ byla v léčbě hyperlipidémie u albinotických králíků stejně účinná jako Simvastatin v dávce $0.6 \mathrm{mg} / \mathrm{kg}$ živé hmotnosti. Tyto dvě substance ve zmíněných dávkách také významně redukovaly obsah cholesterolu v jaterní tkáni. Lze tedy předpokládat, že mechanismus účinku těchto substancí snižujících obsah lipidů v krvi, spočívá ve zvýšeném vylučování nebo katabolismu lipoproteinů, inhibici HMGCoA reduktázy, a/nebo inhibici lyzozomálních hydrolytických enzymů zapojených v metabolismu lipidů syntetizovaných v játrech. 


\section{References}

Aftab K, Rahman A, Ghan KU 1995: Blood pressure lowering action of active principle from Trachyspermum ammi (L.) Sprague. Phytomedicine 2: 35-40

Anderson K, Castelli W, Levy D 1987: Cholesterol and mortality: 30 years of follow up from Framingham Study. J Am Med Assoc 257: 2176

Bhandari U, Grover JK, Sharma JN 2002: Effect of indigenous drugs on changes in morphology and cholesterol level of aorta in early atherosclerotic progression. Hamdard Med 4: 56-59

Blankenhorn DH 1989: Regression of atherosclerosis: dietary and pharmacologic approach. Canadian J Cardiol 54: 206

Carlson LA, Bottiger LE 1981: Serum triglycerides, to be or not to be a risk factor for ischemic heart disease. Atherosclerosis 39: 287-291

Choi JS 1991: Antihyperlipidaemic effect of flavonoids from Prunus davidiana. J Natural Prod 54: 218-224

Chopra RN 1985: Indigenous Drugs of India. U and Dhar Private Limited, India

Dwivedi SK, Dubey NK 1993: Potential use of the essential oil of Trachyspermum ammi against seed-born fungi of guar. Mycopathalogia 121: 101-104

Jahromi MAF, Ray AB, Chansouria JPN 1993: Antihyperlipidaemic effect of flavonoids from Pterocarpus marsupium. J Nat Prod 56: 989-994

Javed I, Akhtar MS, Rahman ZU, Khaliq T, Ahmad M 1994: Comparative anthelmintic efficacy and safety of Caesalpinia crista seed and Piprazine adipate in chickens with artificially induced Ascaradia galli infection. Acta Vet Hung 42: 103-109

Javed I, Iqbal Z, Rahman ZU, Khan FH, Muhammad F, Aslam B, Ali L 2006: Comparative antihyperlipidaemic efficacy of Trachyspermum ammi extracts in albino rabbits. Pakistan Vet J 26: 23-29

Kalhoro MA, Kapadia Z, Badar Y, Hasnain SN 1996: Comparative study of various parameters for hypolipidaemic activity in Lycium europium. Hamdard 34: 16-24

Katzung BG 2001: Basic and Clinical Pharmacology. $8^{\text {th }}$ Ed. Lange Medical Books, McGraw Hill Medical Publishing Division. New York, pp. 581-584

Laurance DR, Bennett PN 1992: Clinical Pharmacology. $7^{\text {th }}$ Ed. Churchill Livingston, UK, pp. $455-457$

Lipid Research Clinical Program 1981: The lipid research clinics coronary primary prevention trial results. Reduction in incidence of coronary heart disease. J Am Med Assoc 251: 351-364

Miura D, Miura Y, Yagasaki K 2003: Hypolipidaemic action of dietary resveratrol, a phytoalexin in grapes and red wine, in hepatoma bearing rats. Life Sci 73: 1393-1400

Purohit A, Daradka HMM 2001: Hypolipidaemic effect of Curcuma loga (Haldi) in rabbits. Hamdard Med XLII: 26-29

Suber P 2005: Effect of leaf juice of Catharanthus roseus Linn on cholesterol triglyceride and lipoprotein levels in normal rats. Indian J Pharmacol 37: 401-402

Shaila HP, Udupa SL, Udupa AL, 1997: Hypolipidemic effect of Terminalia arjuna in cholesterol fed rabbits. Fitoterapia 68: 405-409

Sharma SB, Nasir A, Prabhu KN, Murthy PS, Dev G 2003: Hypoglycaemic and hypolipidaemic effect of ethanolic extract of seeds of Eugenia jambolana in alloxan-induced diabetic rabbits. Ethnopharmacol 85: 201-206

Srivastava KC 1988: Extract of Trachyspermum ammi shows antiaggregatory effects and alters arachidonic acid metabolism in human platelets. Prostaglandins Leukot Essen Fatty Acid 33: 1-6

Visavadiya NP, Narasimhacharya AVRL 2005: Hypolipidaemic and antioxidant activity of Asparagus recemosus in hypercholesteremic rats. Indian J Pharmacol 37: 376-380

Wei W, Li C, Wang Y, Su Y, Zhu J, Kritchevsky D 2003: Hypolipidaemic and anti-atherogenic effect of long term Cholestin (Monascus purpureus-fermented rice, red yeast rice) in cholesterol fed rabbits. J Nutr Boichem 14: 314-318 
